\title{
Front Matter: Volume 7819
}

, "Front Matter: Volume 7819," Proc. SPIE 7819, Instruments, Methods, and Missions for Astrobiology XIII, 781901 (6 October 2010); doi:

10.1117/12.881052

SPIE Event: SPIE Optical Engineering + Applications, 2010, San Diego, California, SPIE. United States 


\section{PROCEEDINGS OF SPIE}

\section{Instruments, Methods, and Missions for Astrobiology XIII}

Richard B. Hoover

Gilbert V. Levin

Alexei Yu. Rozanov

Paul C. W. Davies

Editors

3-5 August 2010

San Diego, California, United States

Sponsored and Published by

SPIE

Volume 7819

Proceedings of SPIE, 0277-786X, v. 7819 
The papers included in this volume were part of the technical conference cited on the cover and title page. Papers were selected and subject to review by the editors and conference program committee. Some conference presentations may not be available for publication. The papers published in these proceedings reflect the work and thoughts of the authors and are published herein as submitted. The publisher is not responsible for the validity of the information or for any outcomes resulting from reliance thereon.

Please use the following format to cite material from this book:

Author(s), "Title of Paper," in Instruments, Methods, and Missions for Astrobiology XIII, edited by Richard B. Hoover, Gilbert V. Levin, Alexei Yu. Rozanov, Paul C. W. Davies, Proceedings of SPIE Vol. 7819 (SPIE, Bellingham, WA, 2010) Article CID Number.

ISSN 0277-786X

ISBN 9780819483157

Published by

SPIE

P.O. Box 10, Bellingham, Washington 98227-0010 USA

Telephone +1 3606763290 (Pacific Time) · Fax +1 3606471445

SPIE.org

Copyright (C) 2010, Society of Photo-Optical Instrumentation Engineers

Copying of material in this book for internal or personal use, or for the internal or personal use of specific clients, beyond the fair use provisions granted by the U.S. Copyright Law is authorized by SPIE subject to payment of copying fees. The Transactional Reporting Service base fee for this volume is $\$ 18.00$ per article (or portion thereof), which should be paid directly to the Copyright Clearance Center (CCC), 222 Rosewood Drive, Danvers, MA 01923. Payment may also be made electronically through CCC Online at copyright.com. Other copying for republication, resale, advertising or promotion, or any form of systematic or multiple reproduction of any material in this book is prohibited except with permission in writing from the publisher. The CCC fee code is 0277-786X/10/\$18.00.

Printed in the United States of America.

Publication of record for individual papers is online in the SPIE Digital Library.

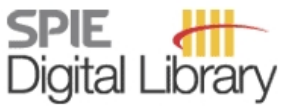

SPIEDigitalLibrary.org

Paper Numbering: Proceedings of SPIE follow an e-First publication model, with papers published first online and then in print and on CD-ROM. Papers are published as they are submitted and meet publication criteria. A unique, consistent, permanent citation identifier (CID) number is assigned to each article at the time of the first publication. Utilization of CIDs allows articles to be fully citable as soon they are published online, and connects the same identifier to all online, print, and electronic versions of the publication. SPIE uses a six-digit CID article numbering system in which:

- The first four digits correspond to the SPIE volume number.

- The last two digits indicate publication order within the volume using a Base 36 numbering system employing both numerals and letters. These two-number sets start with 00, 01, 02, 03, 04, $05,06,07,08,09,0 A, 0 B \ldots 0 Z$, followed by 10-1Z, 20-2Z, etc.

The CID number appears on each page of the manuscript. The complete citation is used on the first page, and an abbreviated version on subsequent pages. Numbers in the index correspond to the last two digits of the six-digit CID number. 


\section{Contents}

ix Conference Committee

\section{SESSION 1 KEYNOTE SESSION}

781902 SETI turns 50: five decades of progress in the search for extraterrestrial intelligence (Keynote Paper) [7819-01]

J. C. Tarter, A. Agrawal, R. Ackermann, P. Backus, S. K. Blair, M. T. Bradford, G. R. Harp, J. Jordan, T. Kilsdonk, SETI Institute (United States); K. E. Smolek, Maxima Software Inc. (United States); J. Richards, J. Ross, G. S. Shostak, D. Vakoch, SETI Institute (United States)

\section{SESSION 2 BIOMARKERS IN TERRESTRIAL ROCKS AND METEORITES I}

781903 Chiral biomarkers and microfossils in carbonaceous meteorites (Invited Paper) [7819-02] R. B. Hoover, NASA Marshall Space Flight Ctr. (United States)

781904 Pathways for the asymmetric amplification of protein amino acids in the Murchison meteorite (Invited Paper) [7819-03]

M. H. Engel, The Univ. of Oklahoma (United States); S. A. Macko, Univ. of Virginia (United States)

\section{SESSION 3 BIOMARKERS IN TERRESTRIAL ROCKS AND METEORITES II}

781905 Review on the origin of oil and hydrocarbon gases within our solar system: biogenic or abiogenic? (Invited Paper) [7819-04]

P. K. Mukhopadhyay, Global Geoenergy Research Ltd. (Canada); D. J. Mossman, J. M. Ehrman, Mt. Allison Univ. (Canada)

781906 The distribution and stereochemistry of amino acids in rocks and sediments from harsh terrestrial environments: analogues for future studies of ancient extraterrestrial materials [7819-05]

M. H. Engel, The Univ. of Oklahoma (United States); D. H. Engel, The Univ. of Oklahoma Libraries (United States)

781907 Comparative methods of investigating microfossils in ancient Archaean to Lower Proterozoic (AR-PR1) rocks [7819-06]

M. M. Astafieva, A. Yu. Rozanov, Paleontological Institute (Russian Federation); R. B. Hoover, NASA Marshall Space Flight Ctr. (United States)

781908 Early Precambrian pillow lavas as habitat for microfossils (Invited Paper) [7819-07] M. M. Astafieva, A. Yu. Rozanov, Paleontological Institute (Russian Federation); M. M. Bogina, A. V. Chistyakov, E. V. Sharkov, Institute of Geology of Ore Deposits, Petrography, Mineralogy, and Geochemistry (Russian Federation); R. B. Hoover, NASA Marshall Space Flight Ctr. (United States) 
781909 Solventless and solid-state reactions as applied to the meteoritic chemistry (Invited Paper) [7819-08]

V. M. Kolb, Univ. of Wisconsin, Parkside (United States)

7819 OA Role of the observer in the scientific process in astrobiology and in defining life [7819-09] V. M. Kolb, Univ. of Wisconsin, Parkside (United States)

SESSION 4 INSTRUMENTATION FOR ASTROBIOLOGY

7819 OB Instrument and materials development in Raman spectroscopy detection and imaging techniques for supporting planetary explorations (Invited Paper) [7819-10]

T. Tran, Univ. of Wisconsin-Madison (United States); Z. Tanaka, Univ. of California, Santa Cruz (United States); C. Jiang, Univ. of South Dakota (United States); C. Burkhard, C. McKay, NASA Ames Research Ctr. (United States); Q. Pei, Univ. of California, Los Angeles (United States);

B. Chen, Univ. of California, Santa Cruz (United States) and NASA Ames Research Ctr. (United States)

7819 OD Evolution of primordial planets in relation to the cosmological origin of life (Invited Paper) [7819-41]

N. C. Wickramasinghe, J. H. Wallis, Cardiff Univ. (United Kingdom); C. H. Gibson, Univ. of California, San Diego (United States); R. E. Schild, Harvard-Smithsonian Ctr. for Astrophysics (United States)

7819 OE Integrated ray tracing simulation of annual variation of spectral bio-signatures from cloud free 3D optical Earth model (Invited Paper) [7819-12]

D. Ryu, S.-W. Kim, Yonsei Univ. (Korea, Republic of); D. W. Kim, College of Optical Sciences, The Univ. of Arizona (United States); J.-M. Lee, Univ. of Oxford (United Kingdom); H. Lee, Univ. of Texas at Austin (United States); W. H. Park, College of Optical Sciences, The Univ. of Arizona (United States); S. Seong, Yonsei Univ. (Korea, Republic of); S.-J. Ham, Univ. of Oxford (United Kingdom)

\section{SESSION 5 ASTROBIOLOGY AND MARS I}

7819 OG Deliquescence, liquid water, and the search for sources and sinks of methane on Mars (Invited Paper) [7819-13]

N. O. Rennó, M. Mehta, Univ. of Michigan (United States)

$7819 \mathrm{OH}$ Solving the problems with chirality as a biomarker for alien life (Invited Paper) [7819-14] G. V. Levin, Arizona State Univ. (United States)

7819 ol Likelihood of methane-producing microbes on Mars (Invited Paper) [7819-15]

J. D. Miller, The Univ. of Southern California (United States); M. J. Case, Univ. of California, Irvine (United States); P. A. Straat, National Institutes of Health (United States); G. V. Levin, Arizona State Univ. (United States) 
7819 OK Astrobiological characteristics and possibility of life in the polar dark dune spots of Mars (Invited Paper) [7819-17]

A. Kereszturi, Sz. Bérczi, A. Horváth, Collegium Budapest (Hungary) and Eötvös Loránd Univ. (Hungary); T. Pócs, Eötvös Loránd Univ. (Hungary) and Eszterházy Károly College (Hungary); A. Sik, Collegium Budapest (Hungary) and Eötvös Loránd Univ. (Hungary); E. Szathmáry, Collegium Budapest (Hungary)

7819 OL Planetary protection protocol using multi-jet cold plasma decontamination [7819-18] G. A. Konesky, K-Plasma Ltd. (United States)

\section{SESSION 7 MICROBIAL EXTREMOPHILES I}

$7819 \mathrm{ON} \quad$ Growth and replication of red rain cells at $121^{\circ} \mathrm{C}$ and their red fluorescence [7819-42] R. Gangappa, Univ. of Glamorgan (United Kingdom) and Cardiff Univ. (United Kingdom; C. Wickramasinghe, Cardiff Univ. (United Kingdom); M. Wainwright, The Univ. of Sheffield (United Kingdom); A. S. Kumar, G. Louis, Cochin Univ. of Science \& Technology (India)

781900 Development of an autofluorescence spectral database for the identification and classification of microbial extremophiles (Invited Paper) [7819-20]

J. Davis, H. Howard, Delaware State Univ. (United States); R. B. Hoover, NASA Marshall Space Flight Ctr. (United States); C. R. Sabanayagam, Delaware State Univ. (United States)

7819 OP Utilization of alternate chirality enantiomers in microbial communities [7819-21] E. V. Pikuta, R. B. Hoover, National Space Science and Technology Ctr. (United States) and NASA Marshall Space Flight Ctr. (United States)

$78190 Q \quad$ Survival of Bacillus pumilus SAFR-032 in simulated Mars atmosphere in real space conditions (Invited Paper) [7819-23]

P. A. Vaishampayan, Jet Propulsion Lab. (United States); G. E. Fox, Univ. of Houston (United States); K. Venkateswaran, Jet Propulsion Lab. (United States)

7819 OR Growth characteristics of red rain microbes at temperatures below $100{ }^{\circ} \mathrm{C}$ (Invited Paper) [7819-24]

G. Louis, A. S. Kumar, Cochin Univ. of Science \& Technology (India)

\section{SESSION $8 \quad$ MICROBIAL EXTREMOPHILES II}

7819 OT Archaeon and archaeal virus diversity classification via sequence entropy and fractal dimension (Invited Paper) [7819-26]

G. Tremberger, Jr., V. Gallardo, C. Espinoza, T. Holden, N. Gadura, E. Cheung, P. Schneider, D. Lieberman, T. Cheung, Queensborough Community College (United States)

7819 OU Cyanobacteria gene and protein sequences in diurnal oscillation metabolic processes [7819-27]

G. Tremberger, Jr., T. Holden, E. Cheung, S. Dehipawala, N. Gadura, U. Golebiewska, K. Valentin, M. Smulczeski, W. Satizabal, P. Schneider, D. Lieberman, T. Cheung, Queensborough Community College (United States) 
7819 OV Zn-metalloprotease sequences in extremophiles [7819-28]

T. Holden, S. Dehipawala, U. Golebiewska, E. Cheung, G. Tremberger, Jr., E. Williams,

P. Schneider, N. Gadura, D. Lieberman, T. Cheung, Queensborough Community College (United States)

\section{SESSION 9 LIFE ON EARLY EARTH}

7819 oW Comparison of the microbial diversity and abundance between the freshwater land-locked lakes of Schirmacher Oasis, and the perennially ice-covered Lake Untersee in East Antarctica [7819-22]

J. P. Huang, The Univ. of Alabama at Birmingham (United States); R. B. Hoover, NASA Marshall Space Flight Ctr. (United States) and National Space Science and Technology Ctr. (United States); A. Swain, Geological Survey of India (India); C. Murdock, Jacksonville State Univ. (United States); D. T. Andersen, SETI Institute (United States); A. K. Bej, The Univ. of Alabama at Birmingham (United States)

$78190 Z$ Origins and early evolution of the translation machinery (Invited Paper) [7819-31] G. E. Fox, Univ. of Houston (United States)

SESSION 10 ASTROBIOLOGICAL MOLECULES, MATERIALS, AND METHODS

781910 Chemistry, life, and the search for aliens (Invited Paper) [7819-39]

S. A. Benner, Foundation for Applied Molecular Evolution (United States)

781912 RNA World meets Snowball Earth (Invited Paper) [7819-33]

C. V. Rice, The Univ. of Oklahoma (United States)

781913 Bacterial morphologies in carbonaceous meteorites and comet dust (Invited Paper) [7819-35]

C. Wickramasinghe, M. K. Wallis, Cardiff Univ. (United Kingdom); C. H. Gibson, Univ. of California, San Diego (United States); J. Wallis, S. Al-Mufti, N. Miyake, Cardiff Univ. (United Kingdom)

781914 Primordial planets, comets, and moons foster life in the cosmos (Invited Paper) [7819-34] C. H. Gibson, Univ. of California, San Diego (United States); N. C. Wickramasinghe, Cardiff Univ. (United Kingdom); R. E. Schild, Harvard-Smithsonian Ctr. for Astrophysics (United States)

781915 ExoMars Raman laser spectrometer overview [7819-40]

F. Rull, A. Sansano, Univ. de Valladolid (Spain); E. Díaz, Instituto Nacional de Técnica Aerospacial (Spain); C. P. Canora, Ingenieria y Servicios Aerospaciales, S.A. (Spain); A. G. Moral, Instituto Nacional de Técnica Aerospacial (Spain); C. Tato, SENER Ingeniería y Sistemas S.A. (Spain); M. Colombo, T. Belenguer, M. Fernández, Instituto Nacional de Técnica Aerospacial (Spain); J. A. R. Manfredi, Univ. de Valladolid (Spain); R. Canchal, Instituto Nacional de Técnica Aerospacial (Spain); B. Dávila, Ingeniería y Servicios Aerospaciales, S.A. (Spain); A. Jiménez, P. Gallego, S. Ibarmia, Instituto Nacional de Técnica Aerospacial (Spain); J. A. R. Prieto, A. Santiago, Ingeniería y Servicios Aerospaciales, S.A. (Spain); J. Pla, Univ. de Valladolid (Spain); G. Ramos, C. González, Instituto Nacional de Técnica Aerospacial (Spain) 
781916 The Drake Equation in an astrobiological context [7819-37]

G. A. Konesky, K-Plasma Ltd. (United States)

781917 Proposed mission for in-situ detection of microorganisms in Low Earth Orbit [7819-38] G. A. Konesky, K-Plasma Ltd. (United States)

Author Index 
Downloaded From: https://www.spiedigitallibrary.org/conference-proceedings-of-spie on 26 Apr 2023

Terms of Use: https://www.spiedigitallibrary.org/terms-of-use 


\title{
Conference Committee
}

\author{
Program Track Chairs
}

Stephen M. Hammel, Space and Naval Warfare Systems Center, San Diego (United States)

Alexander M. J. van Eijk, TNO Defense, Security and Safety

(Netherlands)

\section{Conference Chairs}

Richard B. Hoover, NASA Marshall Space Flight Center (United States)

Gilbert V. Levin, Arizona State University (United States)

Alexei Yu. Rozanov, Paleontological Institute (Russian Federation)

Paul C. W. Davies, Arizona State University (United States)

\section{Program Committee}

Marina M. Astafieva, Paleontological Institute (Russian Federation)

Stanley M. Awramik, University of California, Santa Barbara (United States)

Steven A. Benner, Foundation for Applied Molecular Evolution (United States) and The Westheimer Institute for Science and Technology (United States)

Nathalie A. Cabrol, SETI Institute (United States)

Bin Chen, NASA Ames Research Center (United States)

Simon Clemett, NASA Johnson Space Center (United States)

Dale Cruikshank, NASA Ames Research Center (United States)

David W. Deamer, University of California, Santa Cruz (United States)

Michael H. Engel, University of Oklahoma (United States)

Jack D. Farmer, Arizona State University (United States)

George E. Fox, University of Houston (United States)

Victor A. Gallardo, Universidad de Concepción (Chile)

Carl H. Gibson, University of California, San Diego (United States)

Todd M. Holden, Queensborough Community College (United States)

Ákos Kereszturi, Eötvös Loránd University (Hungary)

Paul Knauth, Arizona State University (United States)

Vera M. Kolb, University of Wisconsin, Parkside (United States)

Jere H. Lipps, University of California, Berkeley (United States)

Godfrey Louis, Cochin University of Science \& Technology (India)

Stephen A. Macko, University of Virginia (United States)

David S. McKay, NASA Johnson Space Center (United States)

Joseph D. Miller, The University of Southern California (United States)

Prasanta K. Mukhopadhyay, Global Geoenergy Research Ltd.

(Canada) 
Elena V. Pikuta, National Space Science and Technology Center

(United States)

Nilton O. Rennó, University of Michigan (United States)

Charles V. Rice, The University of Oklahoma (United States)

Dongok Ryu, Yonsei University (Korea, Republic of)

Chandran Sabanayagam, Delaware State University (United States)

Michael C. Storrie-Lombardi, Kinohi Institute (United States)

Jill C. Tarter, SETI Institute (United States)

Charles H. Townes, University of California, Berkeley (United States)

George Tremberger, Jr., Queensborough Community College (United States)

N. Chandra Wickramasinghe, Cardiff University (United Kingdom)

\section{Session Chairs}

1 Keynote Session

Richard B. Hoover, NASA Marshall Space Flight Center (United States)

2 Biomarkers in Terrestrial Rocks and Meteorites I

Gilbert V. Levin, Arizona State University (United States)

Vera M. Kolb, University of Wisconsin, Parkside (United States)

3 Biomarkers in Terrestrial Rocks and Meteorites II

Nilton O. Rennó, University of Michigan (United States)

Marina M. Astafieva, Paleontological Institute (Russian Federation)

$4 \quad$ Instrumentation for Astrobiology

Simon Clemett, NASA Johnson Space Center (United States)

Joseph D. Miller, The University of Southern California (United States)

5 Astrobiology and Mars I

George E. Fox, University of Houston (United States)

Michael H. Engel, The University of Oklahoma (United States)

6 Astrobiology and Mars II

Godfrey Louis, Cochin University of Science \& Technology (India)

Charles V. Rice, The University of Oklahoma (United States)

$7 \quad$ Microbial Extremophiles I

Prasanta K. Mukhopadhyay, Global Geoenergy Research Ltd. (Canada)

Ákos Kereszturi, Eöłvös Loránd University (Hungary) 
8 Microbial Extremophiles II

Nathalie A. Cabrol, SETI Institute (United States)

Stanley M. Awramik, University of California, Santa Barbara (United States)

$9 \quad$ Life on Early Earth

Elena V. Pikuta, National Space Science and Technology Center (United States)

Gregory A. Konesky, K-Plasma Ltd. (United States)

10 Astrobiological Molecules, Materials, and Methods

Alexei Yu. Rozanov, Paleontological Institute (Russian Federation)

Paul Knauth, Arizona State University (United States) 
Downloaded From: https://www.spiedigitallibrary.org/conference-proceedings-of-spie on 26 Apr 2023

Terms of Use: https://www.spiedigitallibrary.org/terms-of-use 